\title{
Lost life years due to premature mortality caused by diseases of the respiratory system
}

\author{
Irena Maniecka-Bryła ${ }^{1, A, F}$, Paulina Paciej-Gołębiowska ${ }^{1, C, D}$, Elżbieta Dziankowska-Zaborszczyk1,B, Marek Bryła2,E \\ ${ }^{1}$ Department of Epidemiology and Biostatistics, Medical University of Lodz, Poland \\ 2 Department of Social Medicine, Medical University of Lodz, Poland \\ A - research concept and design; B - collection and/or assembly of data; C - data analysis and interpretation; \\ $D$ - writing the article; $E$ - critical revision of the article; $F$ - final approval of the article
}

Address for correspondence

Paulina Paciej-Gołębiowska

E-mail: paulina.paciej@stud.umed.lodz.pl

\section{Funding sources}

The study was financed by the National

Science Center based on decision

No. DEC-2013/11/B/HS4/00465.

\section{Conflict of interest}

None declared

Received on December 1, 2016

Reviewed on February 1, 2017

Accepted on February 28, 2017
DOI

10.17219/acem/69227

\section{Copyright}

Copyright by Author(s)

This is an article distributed under the terms of the

Creative Commons Attribution Non-Commercial License

(http://creativecommons.org/licenses/by-nc-nd/4.0/)

\begin{abstract}
Background. In Poland, as in most other European countries, diseases of the respiratory system are the $4^{\text {th }}$ leading cause of mortality; they are responsible for about $8 \%$ of all deaths in the European Union (EU) annually. To assess the socio-economic aspects of mortality, it has become increasingly common to apply potential measures rather than conventionally used ratios.
\end{abstract}

Objectives. The aim of this study was to analyze years of life lost due to premature deaths caused by diseases of the respiratory system in Poland from 1999 to 2013.

Material and methods. The study was based on a dataset of 5,606,516 records, obtained from the death certificates of Polish residents who died between 1999 and 2013. The information on deaths caused by diseases of the respiratory system, i.e., coded as J00-J99 according to the International Statistical Classification of Diseases and Related Health Problems, 10 ${ }^{\text {th }}$ revision (ICD-10), was analyzed. The Standard Expected Years of Life Lost (SEYLL) indicator was used in the study.

Results. In the years 1999-2013, the Polish population suffered 280,519 deaths caused by diseases of the respiratory system (4.69\% of all deaths). In the period analyzed, a gradual decrease in the standardized death rate was observed - from 46.31 per 100,000 inhabitants in 1999 to 41.02 in 2013. The dominant causes of death were influenza and pneumonia (J09-J18) and chronic lower respiratory diseases (J40-J47). Diseases of the respiratory system were the cause of 4,474,548.92 lost life years. The Standard Expected Years of Life Lost per person (SEYLL) was 104.72 per 10,000 males and 52.85 per 10,000 females. The Standard Expected Years of Life Lost per death (SEYLL $)$ for people who died due to diseases of the respiratory system was 17.54 years of life on average for men and 13.65 years on average for women.

Conclusions. The use of the SEYLL indicator provided significant information on premature mortality due to diseases of the respiratory system, indicating the fact that they play a large role in the health status of the Polish population.

Key words: years of life lost, premature mortality, respiratory system, Poland 


\section{Introduction}

Diseases of the respiratory system are an important health problem faced by the population of Europe. It is estimated that they cause about $8 \%$ of all deaths in the European Union (EU) each year. Additionally, in many highly-developed member nations, this percentage is often higher than the EU average, accounting for more than $10 \%$ of deaths (e.g., in 2012: Great Britain - 14.1\%; Denmark - 11.2\%; Belgium - 10.5\%; and the Netherlands - 10.4\%). ${ }^{1}$

In Poland, as in most other European countries, diseases of the respiratory system are the $4^{\text {th }}$ leading cause of mortality, after diseases of the circulatory system, malignant neoplasms, and external causes. ${ }^{2,3}$ However, the proportional mortality rate due to these diseases is lower than the EU average (5.2\% in 2012). On the other hand, the increasing number of deaths caused by diseases of the respiratory system is alarming. ${ }^{1,4}$

To assess the socioeconomic aspects of deaths, it has become increasingly common to apply potential measures which take into account the lifetime potential of the individuals in the population, rather than the conventionally used ratios. ${ }^{5,6}$ These measures consider not only the number of deaths, but also the age of the individuals at the moment of death, so they can be used to analyze the problem of premature mortality. Knowledge about the scope of the problem and its changes over time plays a pivotal role in planning the public health policy in every population. ${ }^{7,8}$

The aim of this study was to assess the years of life lost due to premature deaths caused by diseases of the respiratory system in Poland between 1999 and 2013, using the Standard Expected Years of Life Lost (SEYLL), Standard Expected Years of Life Lost per person (SEYLL $\left.{ }_{\mathrm{p}}\right)$, and Standard Expected Years of Life Lost per death $\left(S E Y L L_{d}\right)$.

\section{Material and methods}

This study was based on a dataset of 5,606,516 records provided by the Statistical Office in Poland, which contained information from the death certificates of Poles who died between 1999 and 2013. The analysis was performed on the records reporting deaths caused by diseases of the respiratory system, i.e., coded as J00-J99 according to the International Statistical Classification of Diseases and Related Health Problems, $10^{\text {th }}$ revision (ICD-10).

In the study, proportional and specific death ratios were used. The measures were standardized using the direct method for age, with the use of the European population as a reference.

The SEYLL indicator was used as a potential measure. It was calculated according to the method developed by Murray and Lopez: ${ }^{5}$

$$
\text { SEYLL }=\sum_{\chi=0}^{\mathrm{I}} \mathrm{d}_{\chi} \mathrm{e}_{\chi}^{*}
$$

where:

$\mathrm{e}_{\chi}^{*}$ - the average life expectancy for a particular age based on a standard population;

$\mathrm{d}_{\chi}$ - the number of deaths at age $\chi$;

$\chi$ - the age of death;

I - the oldest age in the population.

The life expectancies for particular ages were determined from the life tables published by the World Health Organization (WHO) in 2012. ${ }^{9}$ According to this source, the expected lifespan for both genders is 86.02 years. The values given in the table were not adjusted for age or discounted.

In this study, 2 additional calculations were performed: SEYLL ${ }_{p}$, the ratio of the SEYLL to the number of inhabitants of a country in the year analyzed (calculated per 10,000 inhabitants in this study); and SEYLL ${ }_{\mathrm{d}}$, the quotient of the SEYLL and the number of deaths caused by a particular disease, i.e., calculated per 1 death.

\section{Results}

From 1999 to 2013, the Polish population suffered 280,519 deaths caused by diseases of the respiratory system, which accounted for $4.69 \%$ of all deaths. The ratio between men and women was 1.45 (Table 1).

In the period studied, the values of the standardized death rate due to diseases of the respiratory system gradually decreased for both men and women. In 2013, compared to 1999, the value of this rate had decreased by 8.21 for men (per 100,000 males) and by 3.52 for women (per 100,000 females) (Fig. 1).

The majority of deaths attributed to diseases of the respiratory system occurred in the age group of 65 years and above. In 1999, 78.29\% of all deaths of men due to diseases of the respiratory system were noted in this age group, and in 2013 this figure was $77.54 \%$. For women, $87.26 \%$ and $86.71 \%$ of all deaths due to these diseases were found in this age group in 1999 and 2013, respectively.

The prevailing causes of deaths due to diseases of the respiratory system were influenza and pneumonia (J09J18), as well as chronic lower respiratory diseases (J40J47). Over the period analyzed, the percentage of deaths due to influenza and pneumonia increased from 48.01\% to $58.73 \%$, but dropped for all other respiratory diseases; for example, deaths due to chronic lower respiratory diseases fell from $42.59 \%$ to $33.65 \%$.

In 1999, the dominant cause of death due to diseases of the respiratory system among men were chronic lower respiratory diseases, while in 2013 it was influenza and pneumonia. The percentage of male deaths decreased for all other groups of diseases over the period of 1999-2013. Only the group of other respiratory diseases principally affecting the interstitium (J80-J84) demonstrated such high incidence.

For women, on the other hand, while respiratory deaths were predominantly caused by influenza and pneumonia over the study period, the percentage of deaths due to these 
Table 1. Deaths caused by diseases of the respiratory system in Poland from 1999 to 2013

\begin{tabular}{|c|c|c|c|c|c|c|}
\hline \multirow[b]{2}{*}{ Year } & \multicolumn{2}{|c|}{ Men } & \multicolumn{2}{|c|}{ Women } & \multicolumn{2}{|c|}{ General } \\
\hline & number of deaths & $\begin{array}{l}\text { proportional } \\
\text { mortality ratio }\end{array}$ & number of deaths & $\begin{array}{l}\text { proportional } \\
\text { mortality ratio }\end{array}$ & number of deaths & $\begin{array}{l}\text { proportional } \\
\text { mortality ratio }\end{array}$ \\
\hline 1999 & 10,427 & 5.11 & 7,496 & 4.23 & 17,923 & 4.70 \\
\hline 2000 & 10,491 & 5.37 & 7,819 & 4.53 & 18,310 & 4.98 \\
\hline 2001 & 9,284 & 4.81 & 6,474 & 3.80 & 15,758 & 4.34 \\
\hline 2002 & 9,342 & 4.87 & 6,195 & 3.69 & 15,537 & 4.32 \\
\hline 2003 & 10,185 & 5.25 & 7,145 & 4.17 & 17,330 & 4.74 \\
\hline 2004 & 10,175 & 5.23 & 6,697 & 3.97 & 16,872 & 4.64 \\
\hline 2005 & 11,066 & 5.62 & 7,481 & 4.36 & 18,547 & 5.04 \\
\hline 2006 & 11,126 & 5.61 & 7,341 & 4.28 & 18,467 & 5.00 \\
\hline 2007 & 11,778 & 5.82 & 7,644 & 4.37 & 19,422 & 5.15 \\
\hline 2008 & 11,569 & 5.72 & 7,728 & 4.36 & 19,297 & 5.09 \\
\hline 2009 & 12,206 & 5.99 & 8,446 & 4.66 & 20,652 & 5.36 \\
\hline 2010 & 11,487 & 5.75 & 7,846 & 4.39 & 19,333 & 5.11 \\
\hline 2011 & 11,868 & 5.99 & 8,108 & 4.57 & 19,976 & 5.32 \\
\hline 2012 & 11,715 & 5.80 & 8,433 & 4.62 & 20,148 & 5.24 \\
\hline 2013 & 13,106 & 6.50 & 9,841 & 5.30 & 22,947 & 5.92 \\
\hline Total & 165,825 & 5.23 & 114,694 & 4.08 & 280,519 & 4.69 \\
\hline
\end{tabular}

85

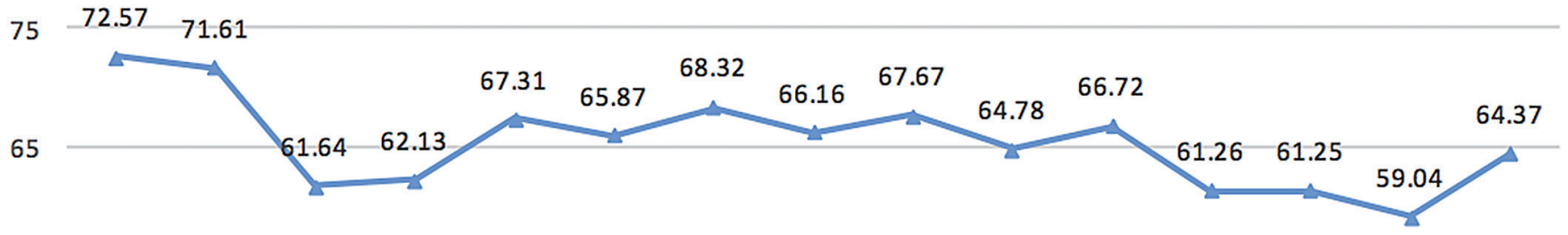

55

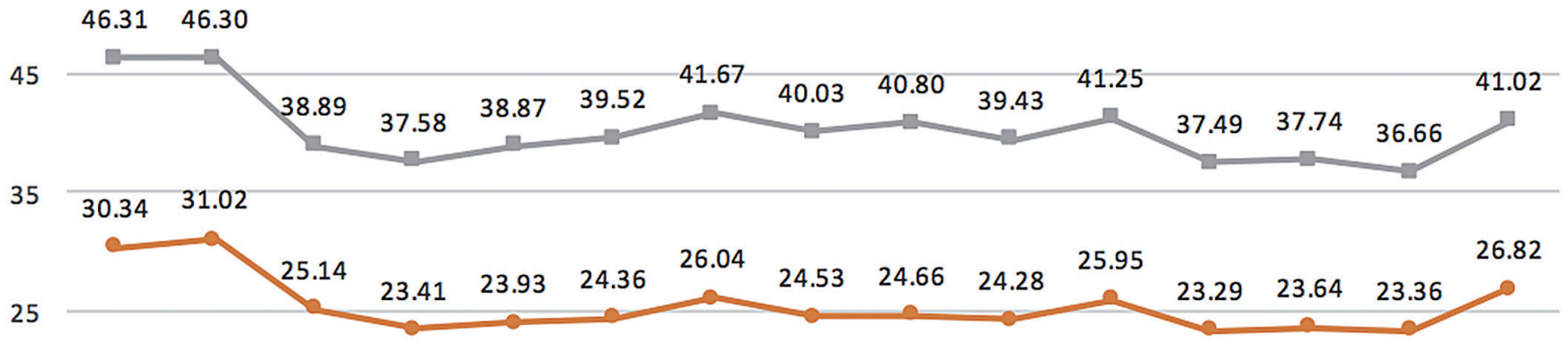

15

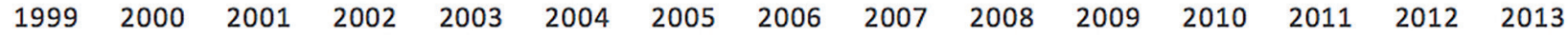

$\simeq$ Men $\longrightarrow$ Women $\longrightarrow$ General

Fig. 1. Standardized death rate due to diseases of the respiratory system in Poland from 1999 to 2013, calculated per 100,000 inhabitants according to sex

diseases grew from $60.22 \%$ to $65.03 \%$ by the end of 2013 . It was also observed that the percentage of deaths caused by lung diseases due to external causes (J60-J70) increased from $1.77 \%$ to $2.02 \%$. The deaths caused by other groups of respiratory diseases fell (Table 2).
In Poland, between 1999 and 2013, deaths due to diseases of the respiratory system accounted for 4,474,548.92 years of lost life (SEYLL): 2,908,777.99 years for men and $1,565,770.93$ years for women. These figures translate to 104.72 prematurely lost life years $\left(S E Y L_{p}\right)$ per 
Table 2. Deaths due to diseases of the respiratory system in Poland in 1999 and 2013 according to cause and sex

\begin{tabular}{|c|c|c|c|c|c|c|}
\hline \multirow{2}{*}{ Cause of death } & \multicolumn{3}{|c|}{1999} & \multicolumn{3}{|c|}{2013} \\
\hline & men & women & general & men & women & general \\
\hline $\begin{array}{l}\text { Acute upper respiratory infections } \\
\text { (J00-J06) }\end{array}$ & $\begin{array}{c}12 \\
(0.12 \%)\end{array}$ & $\begin{array}{c}10 \\
(0.13 \%)\end{array}$ & $\begin{array}{c}22 \\
(0.12 \%)\end{array}$ & $\begin{array}{c}5 \\
(0.04 \%)\end{array}$ & $\begin{array}{c}3 \\
(0.03 \%)\end{array}$ & $\begin{array}{c}8 \\
(0.03 \%)\end{array}$ \\
\hline Influenza and pneumonia (J09-J18) & $\begin{array}{c}4,090 \\
(39.23 \%)\end{array}$ & $\begin{array}{c}4,514 \\
(60.22 \%)\end{array}$ & $\begin{array}{c}8,604 \\
(48.01 \%)\end{array}$ & $\begin{array}{c}7,078 \\
(54.01 \%)\end{array}$ & $\begin{array}{c}6,399 \\
(65.03 \%)\end{array}$ & $\begin{array}{c}13,477 \\
(58.73 \%)\end{array}$ \\
\hline Influenza (J09-J11) & $\begin{array}{c}5 \\
(0.12 \%)\end{array}$ & $\begin{array}{c}4 \\
(0.09 \%)\end{array}$ & $\begin{array}{c}9 \\
(0.10 \%)\end{array}$ & $\begin{array}{c}47 \\
(0.66 \%)\end{array}$ & $\begin{array}{c}50 \\
(0.78 \%)\end{array}$ & $\begin{array}{c}97 \\
(0.72 \%)\end{array}$ \\
\hline Pneumonia (J12-J18) & $\begin{array}{c}4,085 \\
(99.88 \%)\end{array}$ & $\begin{array}{c}4,510 \\
(99.91 \%)\end{array}$ & $\begin{array}{c}8,595 \\
(99.90 \%)\end{array}$ & $\begin{array}{c}7,031 \\
(99.34 \%)\end{array}$ & $\begin{array}{c}6,349 \\
(99.22 \%)\end{array}$ & $\begin{array}{c}13,380 \\
(99.28 \%)\end{array}$ \\
\hline $\begin{array}{l}\text { Other acute lower respiratory infections } \\
(J 20-J 22)\end{array}$ & $\begin{array}{c}55 \\
(0.53 \%)\end{array}$ & $\begin{array}{c}35 \\
(0.47 \%)\end{array}$ & $\begin{array}{c}90 \\
(0.50 \%)\end{array}$ & $\begin{array}{c}11 \\
(0.08 \%)\end{array}$ & $\begin{array}{c}35 \\
(0.36 \%)\end{array}$ & $\begin{array}{c}46 \\
(0.20 \%)\end{array}$ \\
\hline $\begin{array}{l}\text { Other diseases of upper respiratory tract } \\
\text { (J30-J39) }\end{array}$ & $\begin{array}{c}11 \\
(0.11 \%)\end{array}$ & $\begin{array}{c}3 \\
(0.04 \%)\end{array}$ & $\begin{array}{c}14 \\
(0.08 \%)\end{array}$ & $\begin{array}{c}2 \\
(0.02 \%)\end{array}$ & $\begin{array}{c}2 \\
(0.02 \%)\end{array}$ & $\begin{array}{c}4 \\
(0.02 \%)\end{array}$ \\
\hline $\begin{array}{l}\text { Chronic lower respiratory diseases } \\
(\mathrm{J} 40-\mathrm{J} 47)\end{array}$ & $\begin{array}{c}5,316 \\
(50.98 \%)\end{array}$ & $\begin{array}{c}2,317 \\
(30.91 \%)\end{array}$ & $\begin{array}{c}7,633 \\
(42.59 \%)\end{array}$ & $\begin{array}{c}5,037 \\
(38.43 \%)\end{array}$ & $\begin{array}{c}2,685 \\
(27.28 \%)\end{array}$ & $\begin{array}{c}7,722 \\
(33.65 \%)\end{array}$ \\
\hline $\begin{array}{l}\text { Chronic obstructive pulmonary disease } \\
(J 40-J 44, J 47)\end{array}$ & $\begin{array}{c}4,444 \\
(83.60 \%)\end{array}$ & $\begin{array}{c}1,706 \\
(73.63 \%)\end{array}$ & $\begin{array}{c}6,150 \\
(80.57 \%)\end{array}$ & $\begin{array}{c}4,819 \\
(95.67 \%)\end{array}$ & $\begin{array}{c}2,372 \\
(88.34 \%)\end{array}$ & $\begin{array}{c}7,191 \\
(93.12 \%)\end{array}$ \\
\hline Asthma (J45-J46) & $\begin{array}{c}872 \\
(16.40 \%)\end{array}$ & $\begin{array}{c}611 \\
(26.37 \%)\end{array}$ & $\begin{array}{c}1,483 \\
(19.43 \%)\end{array}$ & $\begin{array}{c}218 \\
(4.33 \%)\end{array}$ & $\begin{array}{c}313 \\
(11.66 \%)\end{array}$ & $\begin{array}{c}531 \\
(6.88 \%)\end{array}$ \\
\hline $\begin{array}{l}\text { Lung diseases due to external agents } \\
(\mathrm{J} 60-\mathrm{J} 70)\end{array}$ & $\begin{array}{c}245 \\
(2.35 \%)\end{array}$ & $\begin{array}{c}133 \\
(1.77 \%)\end{array}$ & $\begin{array}{c}378 \\
(2.11 \%)\end{array}$ & $\begin{array}{c}254 \\
(1.94 \%)\end{array}$ & $\begin{array}{c}199 \\
(2.02 \%)\end{array}$ & $\begin{array}{c}453 \\
(1.97 \%)\end{array}$ \\
\hline $\begin{array}{l}\text { Other respiratory diseases principally } \\
\text { affecting the interstitium (J80-J84) }\end{array}$ & $\begin{array}{c}290 \\
(2.78 \%)\end{array}$ & $\begin{array}{c}254 \\
(3.39 \%)\end{array}$ & $\begin{array}{c}544 \\
(3.04 \%)\end{array}$ & $\begin{array}{c}366 \\
(2.79 \%)\end{array}$ & $\begin{array}{c}301 \\
(3.06 \%)\end{array}$ & $\begin{array}{c}667 \\
(2.91 \%)\end{array}$ \\
\hline $\begin{array}{l}\text { Suppurative and necrotic conditions } \\
\text { of the lower respiratory tract (J85-J86) }\end{array}$ & $\begin{array}{c}165 \\
(1.58 \%)\end{array}$ & $\begin{array}{c}54 \\
(0.72 \%)\end{array}$ & $\begin{array}{c}219 \\
(1.22 \%)\end{array}$ & $\begin{array}{c}159 \\
(1.21 \%)\end{array}$ & $\begin{array}{l}55 \\
(0.56 \%)\end{array}$ & $\begin{array}{c}214 \\
(0.93 \%)\end{array}$ \\
\hline $\begin{array}{l}\text { Other diseases of the pleura } \\
\text { (J90-J94) }\end{array}$ & $\begin{array}{c}53 \\
(0.51 \%)\end{array}$ & $\begin{array}{c}31 \\
(0.41 \%)\end{array}$ & $\begin{array}{c}84 \\
(0.47 \%)\end{array}$ & $\begin{array}{c}32 \\
(0.24 \%)\end{array}$ & $\begin{array}{c}21 \\
(0.21 \%)\end{array}$ & $\begin{array}{c}53 \\
(0.23 \%)\end{array}$ \\
\hline $\begin{array}{l}\text { Other diseases of the respiratory system } \\
\text { (J95-J99) }\end{array}$ & $\begin{array}{c}190 \\
(1.82 \%)\end{array}$ & $\begin{array}{c}145 \\
(1.93 \%)\end{array}$ & $\begin{array}{c}335 \\
(1.87 \%)\end{array}$ & $\begin{array}{c}162 \\
(1.24 \%)\end{array}$ & $\begin{array}{c}141 \\
(1.43 \%)\end{array}$ & $\begin{array}{c}303 \\
(1.32 \%)\end{array}$ \\
\hline Total & $\begin{array}{l}10,427 \\
(100 \%)\end{array}$ & $\begin{array}{c}7,496 \\
(100 \%)\end{array}$ & $\begin{array}{l}17,923 \\
(100 \%)\end{array}$ & $\begin{array}{r}13,106 \\
(100 \%)\end{array}$ & $\begin{array}{c}9,841 \\
(100 \%)\end{array}$ & $\begin{array}{l}22,947 \\
(100 \%)\end{array}$ \\
\hline
\end{tabular}

10,000 men, and 52.85 years per 10,000 females. The number of lost life years was found to increase over the period for both men and women, with SEYLL being the highest in the final year of observation: for men it was 118.43 and for women 64.68. SEYLL ${ }_{p}$ for men was lower than 100 only in the years 2001-2004. During this time, the lowest values for women were also recorded $(<50)$.

The analysis of SEYLL $L_{d}$ indicated that a man who died due to a disease of the respiratory system in Poland from 1999 to 2013 lost 17.54 years on average, and a woman 13.65 years on average. Over the period studied, SEYLL fell from 18.55 in 1999 to 16.83 in 2013 for men, and from 14.23 to 13.06 for women (Table 3).

\section{Discussion}

Poland belongs to the group of European countries with a low mortality rate for diseases of the respiratory system, which contribute to about $5 \%$ of all Polish deaths. However, the results of the authors' research indicate that this percentage may increase in the coming years. It was at its highest point in the last year of observation, at $5.92 \%$, which was
$0.62 \%$ higher compared to the previous year and $1.60 \%$ higher than the lowest value recorded during the study period (4.32\% in 2002). In 2012, the highest proportional mortality rate from all the EU countries was noted in Great Britain. It was $14.1 \%$ during that time. The available data indicates that the values of this ratio may also increase in this population. ${ }^{10}$

This study examines the changes in the standardized death rate due to diseases of the respiratory system in Poland. Its value gradually decreased over the study period, but a significant increase was noted in the final year. A similar trend in the standardized death rate was observed for Great Britain and the EU as a whole. ${ }^{4}$ In Poland, the standardized death rate due to diseases of the respiratory system for the general population now has a value almost equal to the EU average (41.02 vs 41.64 per 100,000 inhabitants in 2013). For men, the EU average value was exceeded in 2006, and this upward trend has continued to the present (64.37 vs 47.47 per 100,000 males in 2013). For women, the values were lower than the EU average throughout the entire period analyzed (26.82 vs 31.05 per 100,000 females in 2013).

An analysis of deaths due to diseases of the respiratory system according to age helps in interpreting the changes seen in the values of the standardized death rate and the 
Table 3. Lost life years due to diseases of the respiratory system in Poland from 1999 to 2013 according to sex

\begin{tabular}{|c|c|c|c|c|c|c|}
\hline \multirow[b]{2}{*}{ Year } & \multicolumn{3}{|c|}{ Men } & \multicolumn{3}{|c|}{ Women } \\
\hline & SEYLL & $\begin{array}{c}\text { SEYLL }_{p} \\
(\text { per 10,000) }\end{array}$ & SEYLL $_{d}$ & SEYLL & $\begin{array}{c}\text { SEYLL }_{p} \\
\text { (per 10,000) }\end{array}$ & SEYLL $_{d}$ \\
\hline 1999 & $193,469.35$ & 104.29 & 18.55 & $106,636.32$ & 54.18 & 14.23 \\
\hline 2000 & $190,250.70$ & 102.63 & 18.13 & $110,094.03$ & 55.94 & 14.08 \\
\hline 2001 & $168,229.24$ & 90.80 & 18.12 & $92,308.27$ & 46.89 & 14.26 \\
\hline 2002 & $165,801.98$ & 89.65 & 17.75 & $85,753.37$ & 43.55 & 13.84 \\
\hline 2003 & $178,431.09$ & 96.60 & 17.52 & $97,005.11$ & 49.07 & 13.58 \\
\hline 2004 & $179,390.11$ & 97.21 & 17.63 & $91,381.37$ & 46.44 & 13.65 \\
\hline 2005 & $191,275.33$ & 103.65 & 17.28 & $100,332.88$ & 50.92 & 13.41 \\
\hline 2006 & $195,384.50$ & 106.03 & 17.56 & $99,130.22$ & 50.32 & 13.50 \\
\hline 2007 & $208,624.72$ & 113.31 & 17.71 & $103,710.97$ & 52.63 & 13.57 \\
\hline 2008 & $202,709.79$ & 110.08 & 17.52 & $104,962.05$ & 53.22 & 13.58 \\
\hline 2009 & $214,432.55$ & 116.36 & 17.57 & $116,547.91$ & 59.05 & 13.80 \\
\hline 2010 & $200,072.87$ & 107.26 & 17.42 & $106,641.92$ & 53.65 & 13.59 \\
\hline 2011 & $205,439.20$ & 110.13 & 17.31 & $112,886.45$ & 56.77 & 13.92 \\
\hline 2012 & $194,633.75$ & 104.36 & 16.61 & $109,876.38$ & 55.26 & 13.03 \\
\hline 2013 & $220,632.81$ & 118.43 & 16.83 & $128,503.68$ & 64.68 & 13.06 \\
\hline Total & 2,908,777.99 & 104.72 & 17.54 & $1,565,770.93$ & 52.85 & 13.65 \\
\hline
\end{tabular}

proportional mortality rate over time. The results of the presented study indicate that the highest number of deaths caused by these diseases occurred in people at the age of 65 years or older.

The main respiratory diseases that caused the most deaths in Poland were influenza and pneumonia (J09-J18). An analysis of the number of vaccinations against influenza received by the Polish population suggests that many deaths could be prevented by the vaccine against this virus. ${ }^{11}$ While the European Council recommends that at least $75 \%$ of the population are vaccinated, this number has not exceeded even $5 \%$ in Poland for many years. ${ }^{12,13}$ Moreover, despite the regular advancements in the influenza vaccination, its use has been gradually decreasing in recent years, from $6.8 \%$ in 2009 to $3.4 \%$ in $2015 .^{14,15}$ It is also worth noting that one of the current indications for vaccination against influenza is an age of 65 years or older, regardless of additional risk factors. ${ }^{15,16}$

Beside influenza and pneumonia, the greatest mortality due to diseases of the respiratory system observed in Poland, as in most other European countries, is in chronic lower respiratory diseases (J40-J47), such as bronchial asthma and chronic obstructive pulmonary disease (COPD). ${ }^{1}$ Despite considerable research on the causality of these diseases, certain data on the factors determining their development is lacking. One of the most probable causes of asthma is hypersensitivity to inhaled allergens, and the best documented factor facilitating the progress of asthma is tobacco smoke. ${ }^{17}$ Smoking cigarettes is also a main factor in the progress of COPD. ${ }^{18,19} \mathrm{WHO}$ data indicates that in $2013,29.4 \%$ of Poles aged $\geq 15$ years regularly smoked cigarettes. At the same time, the mean value in the EU was $27.5 \%$, and $20.3 \%$ in Great Britain. ${ }^{4}$
From a socioeconomic point of view, SEYLL is more important than a simple interpretation of death rates. Of particular concern is the significant increase in SEYLL observed in the last year studied. This means that the number of years of life lost due to diseases of the respiratory system calculated per 10,000 inhabitants has increased, and it indicates that there is a need to continue observing premature mortality in the Polish population. Additionally, the decrease in SEYLL ${ }_{d}$ confirms that deaths due to diseases of the respiratory system have shifted to older age groups over time. This may indicate that the prophylactic and therapeutic methods used to treat these diseases have improved.

Diseases of the respiratory system are the $4^{\text {th }}$ highest cause of mortality in Poland, after diseases of the circulatory system, malignant neoplasms, and external causes. Influenza and pneumonia, as well as chronic lower respiratory diseases, including bronchial asthma and chronic obstructive pulmonary disease, are the dominant respiratory diseases contributing to the observed mortality.

The analysis of the health status of a population by a potential measure, like SEYLL, gives significant information on premature mortality. ${ }^{19-22}$ Diseases of the respiratory system over a 15 -year period caused the loss of 4,474,548.92 years of life in the Polish population. This disproportionately affected men, with an average of 104.72 lost life years per 10,000 males, compared to 52.85 lost life years per 10,000 females. This means that, on average, a man who died due to a disease of the respiratory system lost 17.54 years and a woman lost 13.65 years. The values of SEYLL indicate that diseases of the respiratory system play an important socioeconomic role in the health status of the Polish population. 


\section{References}

1. Statistical Office of the European Communities. Respiratory diseases statistics. Eurostat: statistics explained. http://ec.europa.eu/ eurostat/statistics-explained/index.php/Respira-tory_diseases_ statistics. Published October, 2016. Updated December 16, 2016. Accessed December 20, 2016.

2. Dmochowska H, ed. Statistical Yearbook of the Republic of Poland 2015. Warszawa: Central Statistical Office; 2015.

3. World Health Organization. World Health Statistics Report 2008. http://www.who.int/whosis/whostat/EN_WHS08_Full.pdf. Accessed December 20, 2016.

4. World Health Organization Regional Office for Europe. European health for all database. http://data.euro.who.int/hfadb/. Published 2002. Updated June, 2016. Accessed December 20, 2016.

5. Murray CJL, Lopez AD. The Global Burden of Disease. A comprehensive Assessment of Mortality and Disability from Diseases, Injuries and Risk Factors in 1990 and Projected to 2010. Boston, MA: Harvard University Press; 1996.

6. Marshall RJ. Standard Expected Years of Life Lost as a measure of disease burden: An investigation of its presentation, meaning and interpretation. In: Preedy VR, Watson RR, eds. Handbook of Disease Burdens and Quality of Life Measures. Berlin: Springer; 2009:34213434.

7. Selb Semerl J, Sesok J. Years of potential life lost and valued years of potential life lost in assessing premature mortality in Slovenia. CMJ. 2002;43:439-445.

8. Santric Milicevic M, Bjegovic V, Terzic Z, et al. Serbia within the European context: An analysis of premature mortality. Popul Health Metr. 2009;7:12.

9. Supplement to: Murray CJL, Ezzati M, Flaxman AD, et al. GBD 2010 : Design, definitions, and metrics. Lancet. 2012;380:2063-2066.

10. Office for National Statistics. Deaths registered in England and Wales: 2015. http://ons.gov.uk. Published July, 2016. Accessed December 20, 2016.
11. Preaud EDL, Macabeo B, Farkas N, et al. Annual public health and economic benefits of seasonal influenza vaccination: A European estimate. BMC Public Health. 2014;14:813.

12. Council of the European Communities. Proposal for a Council Recommendation on Seasonal Influenza Vaccination. Brussels; 2009.

13. Raise Awareness of Influenza Strategies in Europe. Szczepienia przeciw grypie: podstawowe fakty dla lekarzy pierwszego kontaktu w Europie. Warszawa; 2016.

14. Kolegium Lekarzy Rodzinnych w Polsce. Profilaktyka ileczenie grypy. Łódź; 2006.

15. Ogólnopolski Program Zwalczania Grypy. Raport. Ernst \& Young. http://instytutoz.org/wp-content/uploads/2013/12/Raport_II_Ogolnopolski_Program_Zwalczania_Grypy.pdf. Published June, 2013. Accessed December 20, 2016.

16. Polish Ministry of Health. Komunikat Głównego Inspektora Sanitarnego w sprawie Programu Szczepień Ochronnych na rok 2016. Warszawa: Dziennik Urzędowy Ministra Zdrowia; 2016.

17. Subbarao P, Mandhane PJ, Sears MR. Asthma: Epidemiology, etiology and risk factors. CMAJ. 2009;181(9):E181-E190.

18. Rabe KF, Hurd S, Anzueto A, et al. Global strategy for the diagnosis, management and prevention of chronic obstructive pulmonary disease. Am J Respir Crit Care Med. 2007;6(176):532-555.

19. Shavelle RM, Paculdo DR, Kush SJ, Mannino DM, Strauss DJ. Life expectancy and years of life lost in chronic obstructive pulmonary disease: Findings from the NHANES III Follow-up Study. Int J Chron Obstruct Pulmon Dis. 2009;4:137-148.

20. Maniecka-Bryła I, Bryła M, Bryła P, et al. The burden of premature mortality in Poland analysed with the use of standard expected years of life lost. BMC Public Health. 2015;15:101.

21. Gènova-Maleras R, Catalá-López F, de Larrea-Baz NF, et al. The burden of premature mortality in Spain using standard expected years of life lost: A population-based study. BMC Public Health. 2011;11:787.

22. Burnet NG, Jefferies SJ, Benson RJ, et al. Years of life lost (YLL) from cancer is an important measure of population burden - and should be considered when allocating research funds. Brit J Cancer. 2005;92(2):241-245. 